\title{
REPRODUCTIVE EFFICIENCY AND BEHAVIOR OF PREGNANT SOWS HOUSED IN CAGES AND COLLECTIVE PENS WITH OR WITHOUT BEDDING
}

\author{
Maria L. A. N. Zotti ${ }^{*}$, Késia O. da S. Miranda ${ }^{2}$, Afrânio M. C. Vieira ${ }^{3}$, Joana B. Demsk ${ }^{4}$, \\ Gislaine G. Romano ${ }^{2}$
}

\author{
$1^{1 *}$ Corresponding author. UDESC/ Chapecó - SC, Brasil. \\ E-mail: maria.anunes@udesc.br | ORCID: https://orcid.org/0000-0001-5963-6714
}

\section{KEYWORDS}

animal welfare, environmental enrichment, pigs

\begin{abstract}
This study aimed to evaluate the effect of wood shaving bedding on pregnant sows under two housing conditions. Sixty-four animals were distributed into four treatments, each treatment included 54 sows split into three replicates. A $2 \times 2$ factorial design was used (two types of housing, collective pens $(\mathrm{CP})$ and combined housing (cages $+\mathrm{CP}[\mathrm{CCP}]$ ); and two types of floor, concrete floor without wood shavings (CFWS ${ }^{-}$) and concrete floor with wood shavings $\left(\mathrm{CFWS}^{+}\right)$, allowing establishing the following treatment combinations: $\mathrm{CP}+\mathrm{CFWS}^{+}, \mathrm{CP}+\mathrm{CFWS}^{-}, \mathrm{CCP}+\mathrm{CFWS}^{+}$, and $\mathrm{CCP}+\mathrm{CFWS}^{-}$. Animal behavior, body injuries, reproductive efficiency, and abiotic variables were evaluated. The sows kept on wood shaving bedding presented a higher frequency of standing postures $\left(20.9 \%\right.$ and $31.4 \%$ for $\mathrm{CCP}+\mathrm{CFWS}^{-}$and $\mathrm{CCCP}+\mathrm{CFWS}^{+}$and $20.6 \%$ and $39.2 \%$ for $\mathrm{CP}+\mathrm{CFWS}^{-}$and $\mathrm{CP}+\mathrm{CFWS}^{+}$, respectively). The presence of bedding decreased the occurrence of oral stereotypies and the frequency of injuries in the head, neck/shoulder, and side $\left(12.30 \%\right.$ and $6.02 \%$ for $\mathrm{CCP}+\mathrm{CFWS}^{-}$and $\mathrm{CCCP}+\mathrm{CFWS}^{+}$, and $8.07 \%$ and $5.69 \%$ for $\mathrm{CP}+\mathrm{CFWS}^{-}$and $\mathrm{CP}+\mathrm{CFWS}^{+}$, respectively). The treatments had no effect on stillbirth rates and on the number of piglets born alive, and the number of mummified piglets was higher in $\mathrm{CP}+\mathrm{CFWS}^{+}$than in was in $\mathrm{CCP}+\mathrm{CFWS}^{-}$. However, the presence of bedding changed animal activity and decreased the incidence of injuries.
\end{abstract}

\section{INTRODUCTION}

A primary focus of the discussion on animal welfare is the use of cages in pig farming. Restriction of movements is the main concern and has fostered the creation and implementation of legislation prohibiting the use of cages during gestation (Coser, 2014). The use of cages in breeding sows during gestation was banned in the European Union and in several North American states. The practice was terminated in New Zealand in 2015 and Australia in 2017 (PORKWORD, 2015). In South Africa, the national association of pig farmers intends to eliminate this practice by 2020 .

In Brazil, most of the production systems still use individual cages, but this scenario began to change. The world's leading animal meat processing and pig production companies, including JBS and BRF, recently announced the migration of their supply chain to the collective housing of sows, in all their farms. The policy has also been extended to all contracted suppliers. JBS reported that the whole production chain will be restructured by 2025 (PORKWORD, 2015). It should be noted that the reproductive impact of this management strategy in comparison with gestation under collective housing systems is controversial (Arey \& Edwards, 1998; Cassar et al., 2008). The social aggressiveness observed in housing systems for pregnant sows is considered an animal welfare problem, which brings physiological and behavioral impacts to piglets (Ison et al., 2010).

Therefore, the type of flooring is a decisive element in the behavior pattern of pigs, considering that posture is changed in high-temperature environments (Savary et al., 2009, Lima et al., 2011). The use of bedding in pig farming is associated with the incidence of thermal stress in animals (Sousa et al., 2014). Lower bedding depths allow better environmental conditioning of the productive system (Corrêa et al., 2009), which may be a promising strategy for raising pregnant sows. In this context, the alternative use of bedding during gestation is strengthened when this substrate is considered to stimulate the

\footnotetext{
${ }^{2}$ Escola Superior de Agricultura "Luiz de Queiroz" - Universidade de São Paulo/ Piracicaba - SP, Brasil.

${ }^{3}$ Universidade Federal de São Carlos/ São Carlos - SP, Brazil.

${ }^{4}$ Ji-Paraná/ Rondônia - Brasil. (Não têm instituição atualmente)

Received in: 3-17-2017
}

Accepted in: 2-7-2019 
exploratory behavior of animals (Fraser et al., 1991, Oliva et al., 2014). In view of the above, the objective of this study is to assess the effect of using two housing systems (collective and combined) and bedding for pregnant sows regarding behavior, body injuries, and reproductive efficiency.

\section{MATERIAL AND METHODS}

The study was conducted in a commercial farm located in the municipality of Itu, São Paulo state, Brazil, in the gestation period, from June to September of 2010. A total of 216 animals were evaluated, distributed in four treatments, and each treatment included 54 sows divided into three replicates. Each replicate contained 18 sows, which were housed in $\mathrm{CP}$ at the stocking rate of $2.5 \mathrm{~m}^{2}$ per sow, with a total area per pen of $45 \mathrm{~m}^{2}$, and each pen was considered an experimental unit. The productive environments of treatments $\mathrm{CCCP}+\mathrm{CFWS}^{+}$and $\mathrm{CP}+\mathrm{CFWS}^{+}$were different from those of $\mathrm{CCP}+\mathrm{CFWS}^{-}$ and $\mathrm{CP}+\mathrm{CFWS}^{-}$. In $\mathrm{CCCP}+\mathrm{CFWS}^{+}$and $\mathrm{CP}+\mathrm{CFWS}^{+}$, the animals were maintained on a $0.25-\mathrm{m}$ layer of dry wood shavings. The treatments $\mathrm{CCP}+\mathrm{CFWS}^{-}$and $\mathrm{CP}+\mathrm{CFWS}^{-}$ did not have bedding in the pens, and the animals were housed on a concrete floor. To dispose of the waste, the pens of treatments $\mathrm{CCP}+\mathrm{CFWS}^{-}$and $\mathrm{CP}+\mathrm{CFWS}^{-}$had slopes and gutters in the longitudinal direction, opposite the feeders. In treatments $\mathrm{CCP}+\mathrm{CFWS}^{-}$and $\mathrm{CP}+\mathrm{CFWS}^{-}$, the pens were cleaned daily by removing the waste on the concrete floor. In all treatments, feeding followed the same pattern, and the animals received solid rations in the morning, approximately at 7:00 am. The amount of feed deposited in the feeders was based on a mean daily intake of $2.5 \mathrm{~kg}$ per sow.

The treatments were arranged in a $2 \times 2$ factorial design with two housing conditions and two types of floor. The housing systems consisted of collective pens (CP) and a combined system (cages $+\mathrm{CP}$ ) starting at 28 days of gestation, preceded by the use of cages. Two floor types were used: a concrete floor (CF) and a CF covered with 25-cm wood shavings $\left(\mathrm{CFWS}^{+}\right)$, allowing the following treatment combinations: $\mathrm{CP}+\mathrm{CFWS}^{+}, \mathrm{CP}+\mathrm{CFWS}^{-}$, $\mathrm{CCP}+\mathrm{CFWS}^{+}$, and $\mathrm{CCP}+\mathrm{CFWS}^{-}$. The climatic variables monitored in the study period were temperature and relative air humidity. The data were recorded in 10-min intervals using Hobo ${ }^{\circledR}$ data loggers installed at a height of $1.5 \mathrm{~m}$ at a point representative of the thermal conditions of the pens. Two devices were installed, one in each shed, to concomitantly record the measurements in the pens without bedding $\left(\mathrm{CCP}+\mathrm{CFWS}^{-}\right.$and $\left.\mathrm{CP}+\mathrm{CFWS}^{-}\right)$and with bedding $\left(\mathrm{CCCP}+\mathrm{CFWS}^{+}\right.$and $\left.\mathrm{CP}+\mathrm{CFWS}^{+}\right)$. The temperature and relative air humidity were recorded at 10 min intervals, the data were processed, and the mean values on each day of measurement of physiological parameters were calculated.
This approach allowed estimating the effect of climatic variables on the physiological response of the animals under different treatments. The mean temperatures and relative air humidity were calculated on each day of measurement of physiological parameters: 7:30 a.m., 12:00 p.m., and 4:30 p.m. (designated morning, noon, and afternoon in this study, respectively). The specific air enthalpy values $(\mathrm{kJ} / \mathrm{kg}$ of dry air) obtained from microclimate data were calculated as a thermal variable of the sheds according to [eq. (1)] proposed by Rodrigues et al. (2011)

$h=1,006 \cdot t+\frac{U R}{p b} \cdot 10^{(7,5 \cdot t / 237,3+t)} \cdot(71,28+.0,052 \cdot t)$

Where,

$$
\begin{aligned}
& h=\text { enthalpy }(\mathrm{kJ} / \mathrm{kg} \text { of dry air }) ; \\
& t=\text { dry bulb temperature }\left({ }^{\circ} \mathrm{C}\right) ; \\
& \mathrm{UR}=\text { relative air humidity }(\%) \text { and } \\
& p b=\text { local barometric pressure }(758 \mathrm{mmHg}) .
\end{aligned}
$$

In addition, behavioral parameters were recorded to characterize different stages of gestation, totaling 18 days. Behavior was assessed by focal sampling using six animals from each pen. The animals were previously tagged using non-toxic marker rods $\left(\operatorname{Radex}^{\circledR}\right)$. Animal posture and activity were recorded at 10-min intervals for 1 hour three times a day (7:30 a.m., 12:00 p.m., and 4:30 p.m.). The listed behavioral categories (Table 1) were adapted to the specificities of the experiment using an on-site test and a protocol established by Pandorfi (2005), Karlen et al. (2007), and Munsterhjelm et al. (2009).

The body injuries were analyzed 1 week after transferring the animals to a collective housing system by determining the frequency, severity level, and body location according to the methodology adapted from Jansen et al. (2007) and Karlen et al. al., (2007). Reproductive parameters were also analyzed. Sows were monitored during delivery, and the recorded data were gestation period, number of piglets born alive, number of stillborn piglets, number of mummified piglets, and mean weight of piglets at birth. The data were analyzed using Minitab statistical software version 16 (Minitab 16 Statistical Software, 2011). Animal behavior data were analyzed using descriptive statistics whereas reproductive variables were evaluated using simple linear regression. Data on injuries were analyzed using the chi-square test followed by correspondence analysis in cases in which the chi-square test was significant. 
TABLE 1. Ethogram of the method used in evaluating animal behavior.

\begin{tabular}{|c|c|c|}
\hline Category & Behavior & Description \\
\hline \multirow{4}{*}{ Posture } & Lying & Lying ventrally or laterally \\
\hline & Standing & Standing position \\
\hline & Sitting & Sitting position \\
\hline & Kneeling & Kneeling position \\
\hline \multirow{11}{*}{ Activity } & Inactive & Without apparent activity \\
\hline & Walking & In movement \\
\hline & Interacting with the floor & Manipulating the floor (including bedding) \\
\hline & Interacting with objects & $\begin{array}{c}\text { Interacting with pen components (feeder, walls, and grids) without } \\
\text { characterizing stereotypies }\end{array}$ \\
\hline & Drinking & $\begin{array}{c}\text { Drinking water from the water dispenser or water accumulated in } \\
\text { the feeder }\end{array}$ \\
\hline & Eating & Eating ration from the feeder \\
\hline & Interacting aggressively with other animals & $\begin{array}{c}\text { Interacting aggressively with animals from the same pen (pushing, } \\
\text { biting, chasing, and threatening) }\end{array}$ \\
\hline & Interacting positively with other animals & $\begin{array}{l}\text { Interacting peacefully with animals from the same pen (nibbling, } \\
\text { sniffing, and licking parts of the body) }\end{array}$ \\
\hline & Tongue stereotypies & Moving the tongue repeatedly \\
\hline & Mouth stereotypies & Opening and closing the mouth repeatedly with excessive salivation \\
\hline & Grid stereotypies & Repeatedly biting the pen grids \\
\hline
\end{tabular}

\section{RESULTS AND DISCUSSION}

The characterization of the microclimate at different times of the day was performed using the meteorological data from the sheds with and without bedding. The results of temperature indicated that the thermal condition at these time points was different from the ideal temperature range used by Pandorfi (2005) for pregnant sows $\left(7-23{ }^{\circ} \mathrm{C}\right.$ ) (Figure 1). In the morning, the thermal conditions were adequate on all days of behavioral evaluation (Figure 1). In contrast, mean temperatures above the ideal range were recorded at noon and in the afternoon on most days of behavioral analysis. The mean relative air humidity was considered high in the morning and, to a large extent, low at noon and in the afternoon. Moura (1999) found that the optimal relative air humidity for pregnant sows was $50 \%$ to $70 \%$. Despite the lack of reference range values for suitable air enthalpy for pig growth, the variations in this variable at different times of the day are presented in Figure 1. Dry bulb temperature and relative air humidity were evaluated together in this study, which allowed determining the thermal comfort of the pens (Rodrigues et al., 2011).
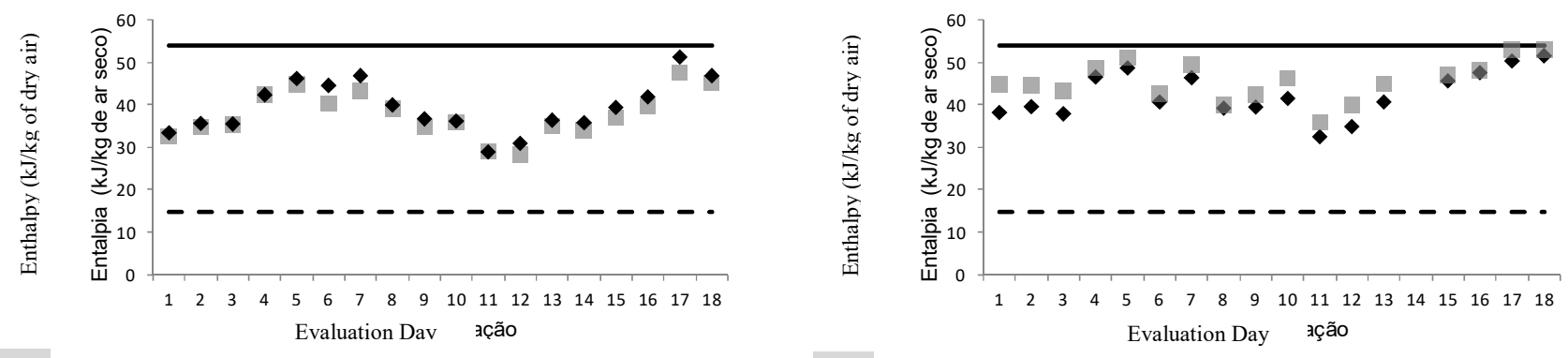

$\mathrm{A} \quad \cdot \mathrm{CC}=\mathrm{CFWS}^{-} \quad-$ HMax $\quad--\mathrm{HMin}^{-}$

$\mathrm{B} \quad \cdot \mathrm{CC}=\mathrm{CFWS}^{-} \quad-\mathrm{HMax} \quad--\mathrm{HMin}$

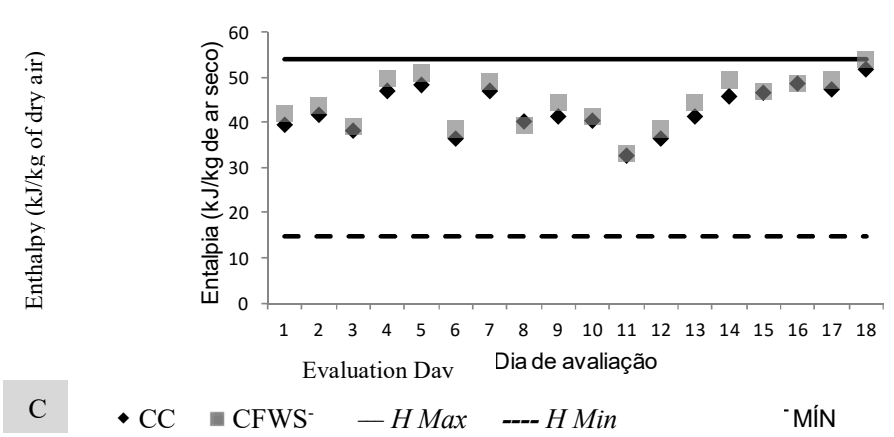

FIGURE 1. Mean air enthalpy (kJ/kg dry air) on the days of analysis of animal behavior in the morning (A), noon (B), and afternoon $(\mathrm{C})$ in collective pens with and without wood shaving bedding. 
However, the thermal comfort ranges used by Pandorfi (2005) and Moura (1999) for air temperature and relative air humidity, respectively, imply considering critical limits of dry air of 14.8 to $53.9 \mathrm{~kJ} / \mathrm{kg}$. The values at different times of the day (Figure 1) usually did not exceed this enthalpy range (Figure 1).

The analysis of animal behavior under different treatments indicated that the presence of bedding increased the frequency of animals in the standing position (Figure 2 and Table 2). The comparison between treatments
$\mathrm{CCP}+\mathrm{CFWS}^{-}$and $\mathrm{CCCP}+\mathrm{CFWS}^{+}$demonstrated that animals in bedded pens remained $10.5 \%$ longer in the standing position than animals kept on concrete floors $(20.9 \%$ and $31.4 \%$ in the standing position for $\mathrm{CCP}+\mathrm{CFWS}^{-}$and $\mathrm{CCCP}+\mathrm{CFWS}^{+}$, respectively). Similarly, a separate analysis of treatments $\mathrm{CP}+\mathrm{CFWS}^{-}$ and $\mathrm{CP}+\mathrm{CFWS}^{+}$evidenced that the frequency of animals in the standing position increased $18.6 \%$ in the presence of bedding $\left(20.6 \%\right.$ and $39.2 \%$ for $\mathrm{CP}+\mathrm{CFWS}^{-}$and $\mathrm{CP}+\mathrm{CFWS}^{+}$, respectively).
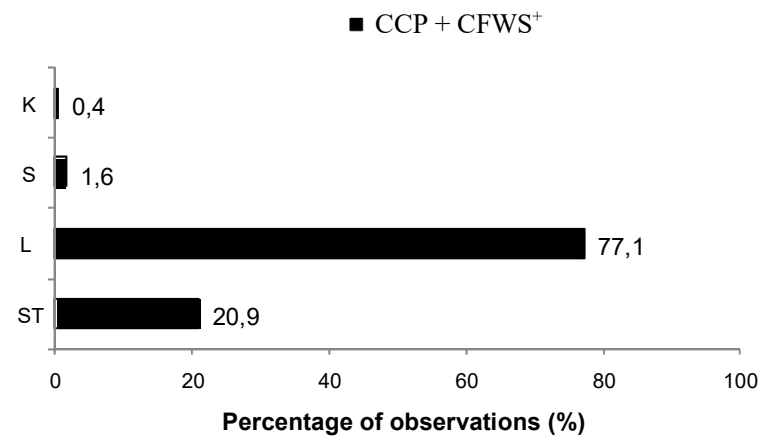

- $\mathrm{CP}+\mathrm{CFWS}$

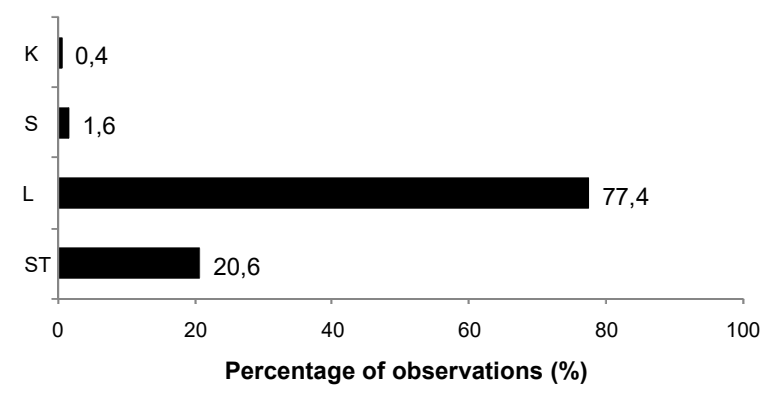

- $\mathrm{CCCP}+\mathrm{CFWS}$
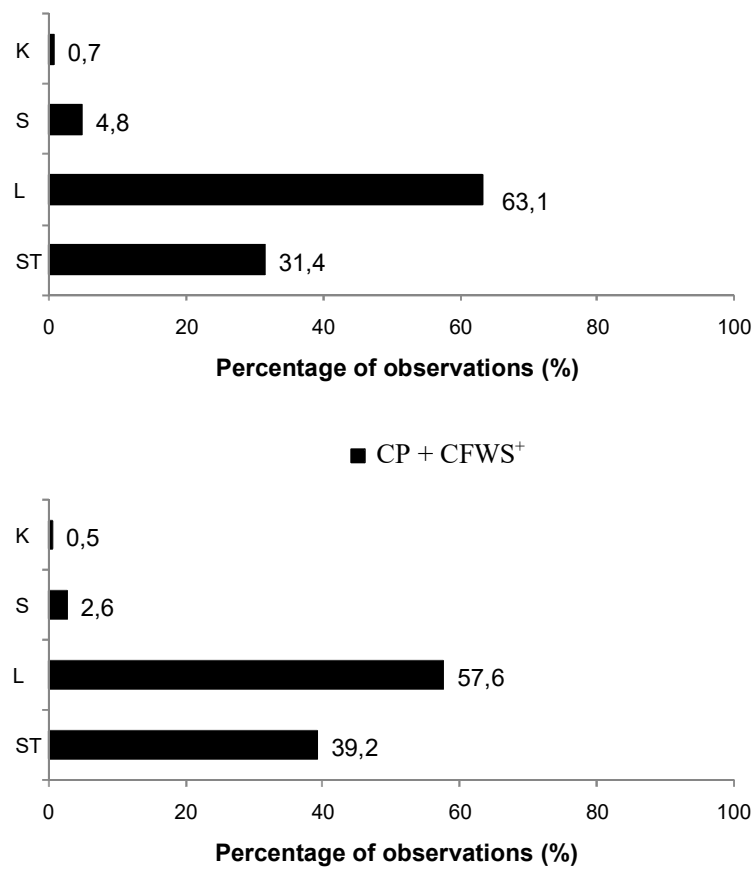

FIGURE 2. Percentage of time spent by pregnant sows in different postures (K, kneeling; S, sitting; L, lying down; and St, standing) in treatments $\mathrm{CCP}+\mathrm{CFWS}^{-}, \mathrm{CCCP}+\mathrm{CFWS}^{+}, \mathrm{CP}+\mathrm{CFWS}^{-}$, and $\mathrm{CP}+\mathrm{CFWS}^{+}$.

Despite the absence of bedding on the pen floor, the treatments $\mathrm{CCP}+\mathrm{CFWS}^{-}$and $\mathrm{CP}+\mathrm{CFWS}^{-}$presented a relatively higher frequency of animals interacting with the floor. Silva et al. (2008) compared pregnant sows grown in collective and individual pens with CFs and classified as behavioral stereotypy the act of rooting the floor without any available substrate. These authors observed that the sows kept in CP remained $7.99 \%$ of the time rooting the floor, which is similar to the results of treatments without bedding $\left(8.20 \%\right.$ in $\mathrm{CCP}+\mathrm{CFWS}^{-}$and $7.90 \%$ in $\mathrm{CP}+\mathrm{CFWS}^{-}$). Jensen et al. (2010) evaluated the effect of the availability of wood shavings in the trough on the behavior of pigs in the growth phase and concluded that in the presence of food restriction without wood shaving bedding, the animals directed their behavior to the exploration of elements of the pen, including the floor. However, the frequency of interactions with the floor in the absence of wood shavings was lower than that in the presence of shavings. These results demonstrate the importance of the existence of substrates for pigs to root, especially when under food restriction (a condition similar to that used for pregnant sows). In addition, these authors observed that the act of rooting the $\mathrm{CF}$ was classified as a behavioral deviation in cases of absence of substrate.
In the treatments with bedding $\left(\mathrm{CCCP}+\mathrm{CFWS}^{+}\right.$and $\mathrm{CP}+\mathrm{CFWS}^{+}$), the animals spent $5.03 \%$ and $11.24 \%$ of their time interacting with the floor, respectively. Karlen et al. (2007) observed that pregnant sows kept in pens containing $30 \mathrm{~cm}$ of rice husk spent $5.9 \%$ of the time (first week of gestation) and $3.3 \%$ of the time (ninth week of gestation) interacting with the floor. These values agree with those of this study despite the methodological differences between the two studies regarding the type of bedding used. Environmental enrichment can modify the behavior of pigs, improving their exploratory behavior (Averós et al., 2010). In contrast, the frequency of abnormal behavior may be higher in poor environments because of the redirection of normal exploratory behavior (Studnitz et al., 2007). The present results indicate that the frequency of behavioral stereotypies was higher in the treatments without bedding $\left(12.76 \%\right.$ in $\mathrm{CCP}+\mathrm{CFWS}^{-}$and $9.65 \%$ in $\mathrm{CP}+\mathrm{CFWS}^{-}$) (Table 2 ). In contrast, the frequency of stereotypies in the presence of bedding was $7.28 \%$ in $\mathrm{CCCP}+\mathrm{CFWS}^{+}$and $7.15 \%$ in $\mathrm{CP}+\mathrm{CFWS}^{+}$. Oral stereotypies often resemble feeding movements that are typical of this ungulate species (Bergeron et al., 2006). Therefore, the percentage of oral stereotypies was high, corresponding to $12.30 \%, 6.02 \%, 8.07 \%$, and $5.69 \%$ in $\mathrm{CCP}+\mathrm{CFWS}^{-}, \quad \mathrm{CCCP}+\mathrm{CFWS}^{+}, \quad \mathrm{CP}+\mathrm{CFWS}^{-}, \quad$ and $\mathrm{CP}+\mathrm{CFWS}^{+}$, respectively. 
Aggressive social behavior was observed in a small proportion of the sample in the different treatments. Silva et al. (2008) found that the frequency of aggressive behaviors in sows kept in $\mathrm{CP}$ containing six animals was low, and this result was attributed to the fact that the animals were kept in the same social group in the study period until artificial insemination. This approach allows establishing social hierarchy before performing social mixing in the gestation period. In turn, under the present experimental conditions, the higher number of sows (18) and the absence of previous social mixing may explain the higher incidence of aggression. The behavioral pattern varied considerably at different times of the day, and animal resting was more frequent at noon and in the afternoon. Regardless of the treatment, the frequency of stereotypies was comparatively higher in the morning, which is related to the period of higher animal activity. In addition, typical oral stereotypies in sows are classified as behaviors derived frustrated foraging, which explains their higher frequency at times close to feeding (Bergeron et al., 2006).

The variation in the postural pattern considering only the lying and standing positions on different days (days 1 to 4 in the $\mathrm{CCP}+\mathrm{CFWS}^{-}$and $\mathrm{CCCP}+\mathrm{CFWS}{ }^{+}$, and days 1 to 7 in $\mathrm{CP}+\mathrm{CFWS}^{-}$and $\mathrm{CP}+\mathrm{CFWS}^{+}$) (Figure 3). The postural pattern was correlated with mean air temperatures. The predominant posture was lying down, except on day 2 , when the percentage of standing postures

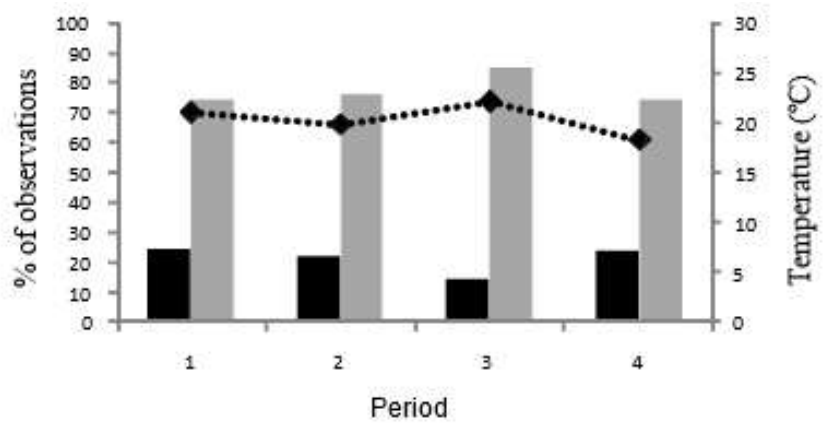

A

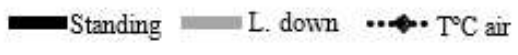

B

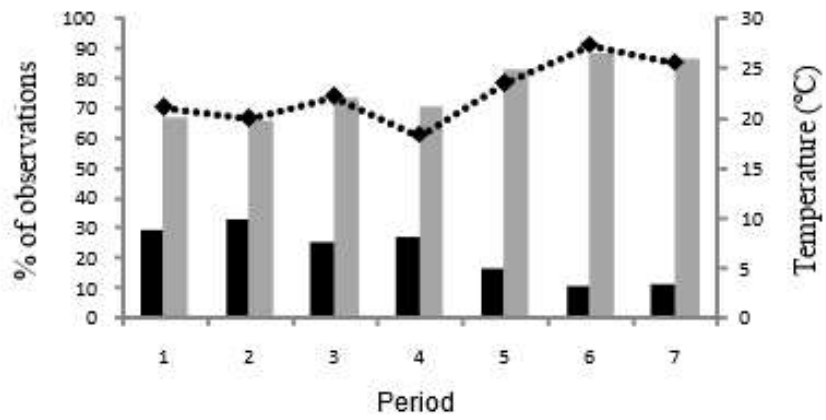

C
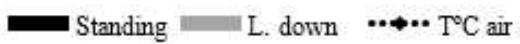

was higher in treatment $\mathrm{CP}+\mathrm{CFWS}+$. The analysis of mean temperatures on each day indicates a possible association between the increase in the time spent in the lying posture and the increase in the mean ambient temperature.

A significant correlation $(p<0.01)$ was observed between the time spent in the lying position and the mean air temperature in the treatments $\mathrm{CP}+\mathrm{CFWS}^{-}$and $\mathrm{CP}+\mathrm{CFWS}^{+}$, with correlations of $\mathrm{r}=0.73$ and $\mathrm{r}=0.77$, respectively. This high and positive correlation evidences that the increase in air temperature strongly affected the behavior pattern of sows, increasing the time spent lying down in these two treatments. Postural changes constitute mechanisms of adjustment to the loss of sensible heat and indicate the thermal state of pigs (Andersen et al., 2008). These results corroborate those of Brown-Brandl et al. (2001) and Kiefer et al. (2009), wherein the time spent in the lying posture was directly correlated with the increase in air temperature.

The results of body injuries are shown in Figure 4. Interestingly, aggressive behavior occurs when sows are mixed to establish social stability (English et al., 1982). Therefore, determining the frequency of injuries of different severities after one week of social mixing is an indirect measure of the aggressive behavior of pregnant sows subjected to different housing and bedding conditions.

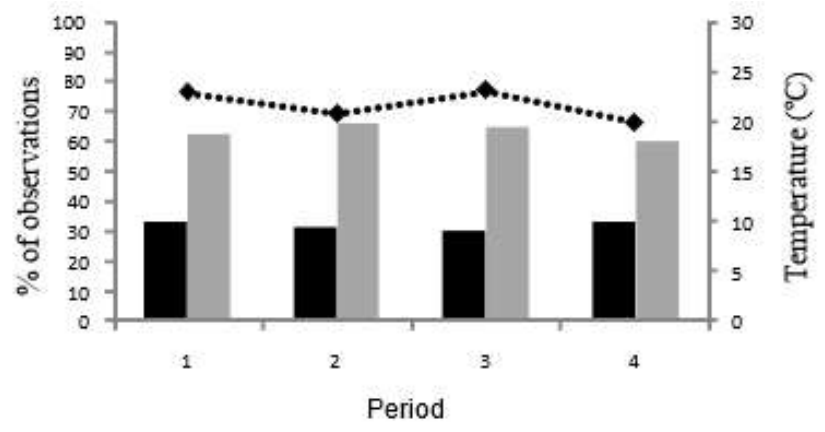

Standing $\mathrm{L}$. down $\cdots \cdots \mathrm{T}^{\circ} \mathrm{C}$ ar
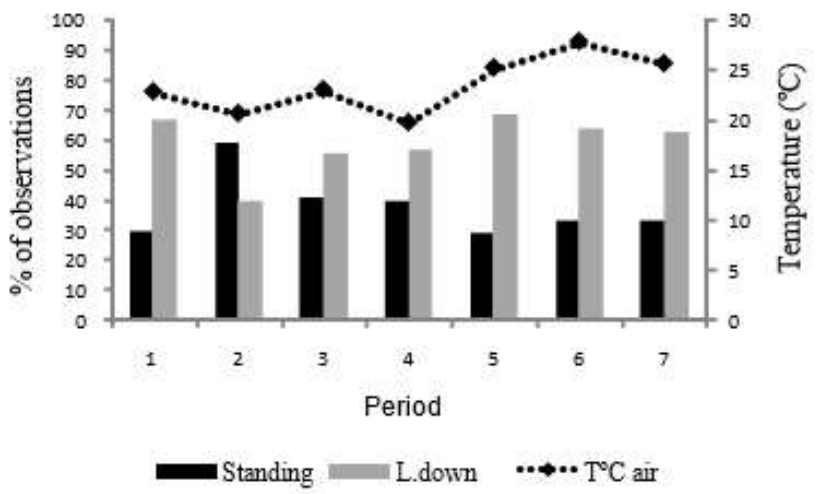

FIGURE 3. Correlation between the percentage of time spent by pregnant sows in different postures and mean air temperature in the treatments $\mathrm{CCP}+\mathrm{CFWS}^{-}(\mathrm{A}), \mathrm{CCCP}+\mathrm{CFWS}^{+}(\mathrm{B}), \mathrm{CP}+\mathrm{CFWS}^{-}(\mathrm{C})$, and $\mathrm{CP}+\mathrm{CFWS}{ }^{+}$(D) (days 1 to 4 in $\mathrm{CCP}+\mathrm{CFWS}$ and $\mathrm{CCCP}+\mathrm{CFWS}^{+}$and days 1 to 7 in $\mathrm{CP}+\mathrm{CFWS}^{-}$and $\mathrm{CP}+\mathrm{CFWS}{ }^{+}$). 
Higher absolute values, specifically of grade I and II injuries, were observed in sows housed in pens without bedding $\left(\mathrm{CP}+\mathrm{CFWS}^{-}\right.$and $\left.\mathrm{CCP}+\mathrm{CFWS}^{-}\right)$. The frequency of injuries in the front region (head, ear, neck/shoulder) was higher than that in the back. These results corroborate those obtained by Remience et al., (2008), who used an injury score to evaluate different stocking rates for sows. The percentage of injuries obtained by these authors was $53 \%, 32 \%$, and $15 \%$ in the front (head, neck, and shoulder), middle (belly and loin), and back (leg, tail, and vulva) regions, respectively. The results of the chi-square test are summarized in Table 2.
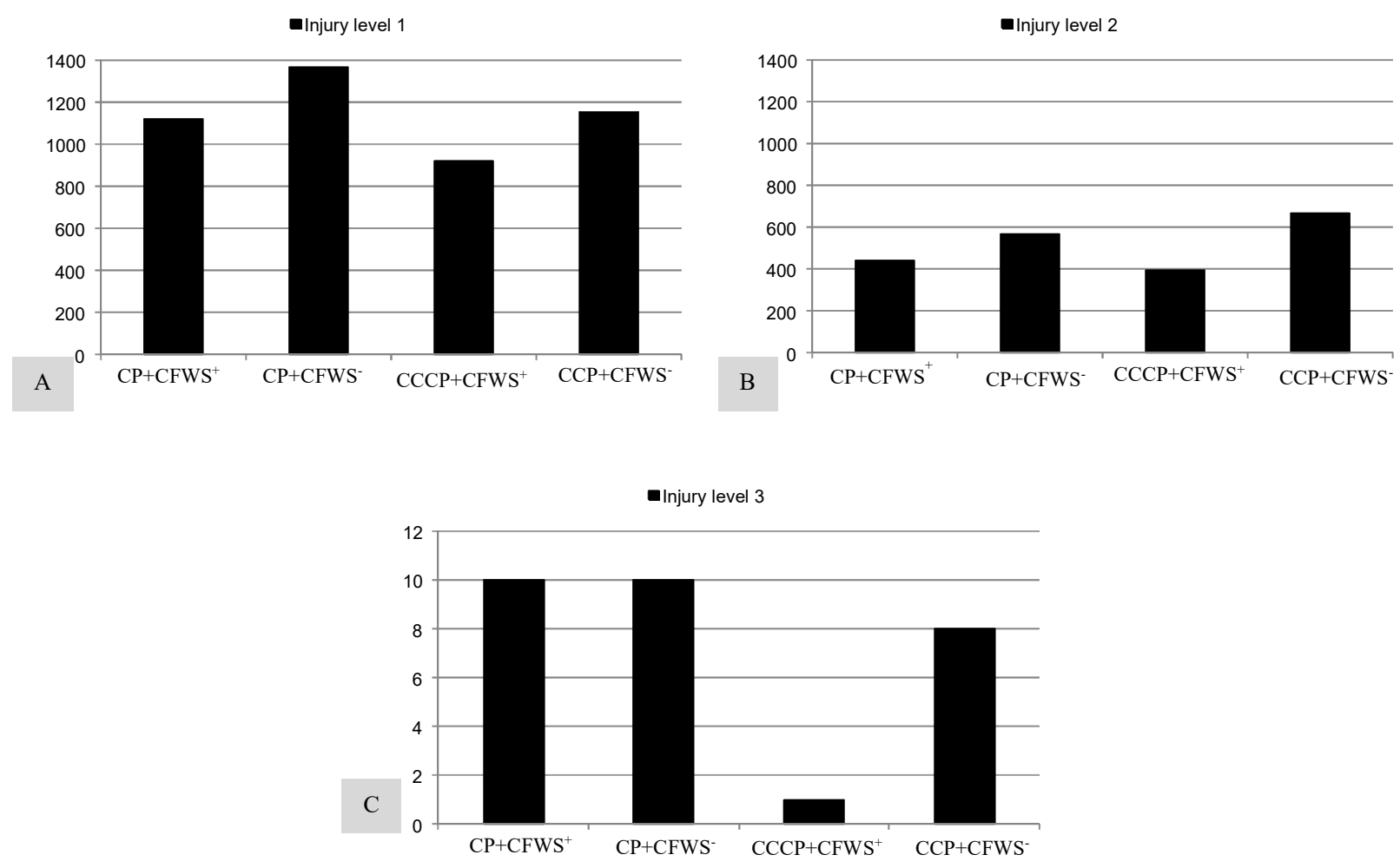

FIGURE 4. Total number of injuries of grades 1 (A), 2 (B), and 3 (C) in different treatments.

The test was significant $(\mathrm{p}<0.05)$ in the head, neck/shoulder, side, and leg. The fifth column of the table shows the most representative combination of treatment and frequency of injuries for the test result to be significant. The results obtained using the chi-square test confirmed the results of the exploratory data analysis (Table 2). The frequency of injuries in treatments with bedding $\left(\mathrm{CCCP}+\mathrm{CFWS}^{+}\right.$in the case of the head, and $\mathrm{CP}+\mathrm{CFWS}^{+}$in the case of the side) was usually lower than the expected values using the chi-square test. Consistent with the results of the exploratory data analysis, the frequency of injuries in treatments without bedding $\left(\mathrm{CCP}+\mathrm{CFWS}^{-}\right.$in the case of the neck/shoulder and leg) was higher than the expected values using the performed test.

Therefore, the present results agree with those of Averós et al. (2010). The meta-analysis performed by these authors indicated that the percentage of time spent in negative social behaviors increased as the group size increased in the absence of bedding but remained practically constant when bedding was available. Therefore, the use of bedding in the model established in the present study caused fewer injuries during social mixing, which indicates the lower frequency of aggressiveness and, therefore, improvement in animal welfare.

TABLE 2. Values obtained using the chi-square (CS) test for each body region in which the test was significant.

\begin{tabular}{ccccccc}
\hline Region & CS & p-value & DF & Higher significance in the test & Expected value & Observed value \\
\hline Head & 22.35 & $<0.001$ & 3 & CCCP + CFWS $^{+}-$grade 2 injuries & 49.53 & 27 \\
Neck/shoulder & 30.25 & $<0.001$ & 3 & ${\text { CCP }+\mathrm{CFWS}^{-}-\text {grade 2 injuries }}$ & 279 & 339 \\
Belly/loin & 7.88 & 0.049 & 3 & $\mathrm{CP}+\mathrm{CFWS}^{+}-$grade 2 injuries & 85.14 & 72 \\
Leg & 8.11 & 0.044 & 3 & $\mathrm{CCP}+\mathrm{CFWS}^{-}-$grade 2 injuries & 57.07 & 72 \\
\hline
\end{tabular}


Mostly, the highest chi-square values were observed in the head and neck/shoulder, which are more strongly affected by aggressive behavior during social mixing. Remience et al. (2008) have shown that injuries in the anterior region (head, ear, and shoulder) are due to fights and aggression whereas injuries in the vulva, tail, and leg originate from competition for food. Therefore, in the present study, injuries in the back were not caused by the type of housing and floor and depended on factors that did not vary in the different treatments, including the stocking rate and feeding management. In the body regions in which the chi-square test was significant, correspondence analysis was performed and generated the graphical representations presented in Figures 5A, B, C, and D for the head, neck/shoulder, belly/loin, and leg, respectively.

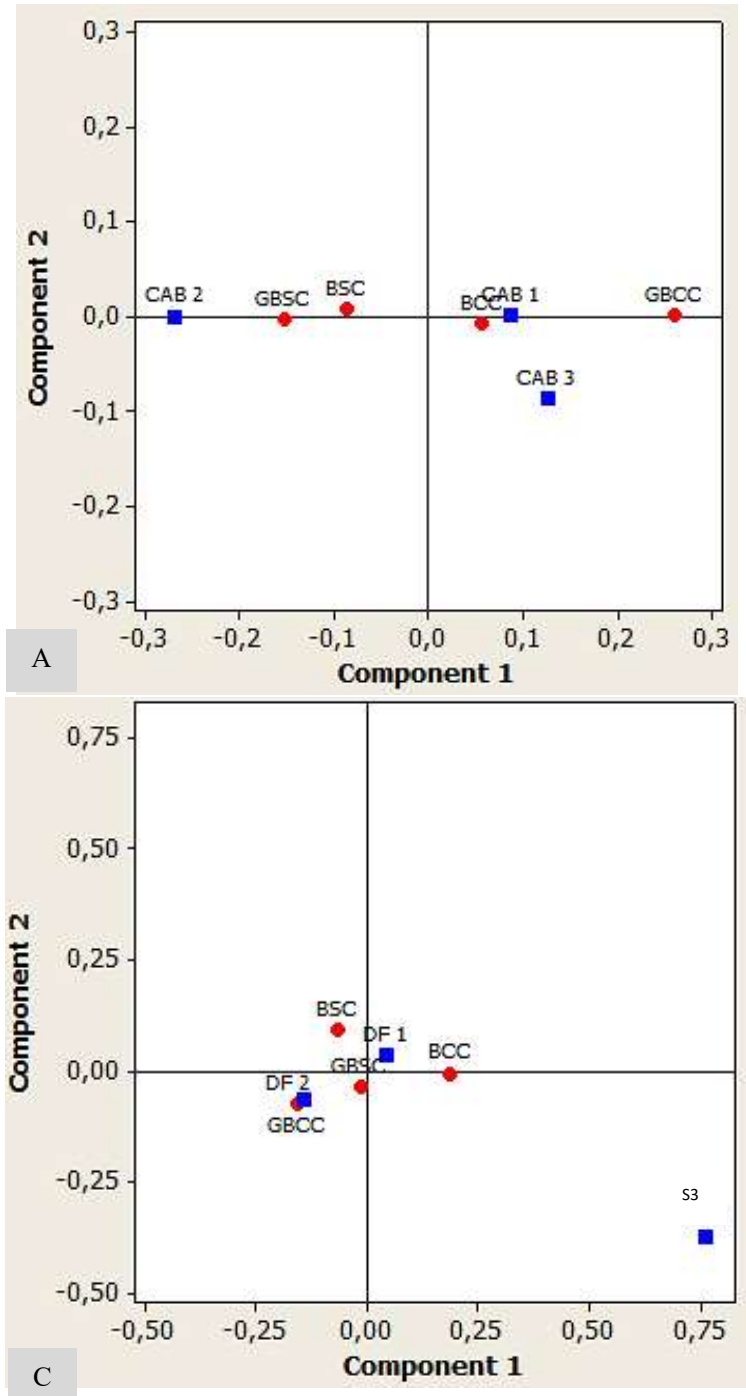

Correspondence analysis for the head region indicated that the components $\mathrm{H} 2$ (grade II injuries in the head) and $\mathrm{CCCP}+\mathrm{CFWS}^{+}$were distant from each other and from the origin (crossing of axes) (Figure $5 \mathrm{~A}$ ). The large distance from the origin confirms that the contribution of both variables to the chi-square test is large. In addition, the fact that $\mathrm{H} 2$ and $\mathrm{CCCP}+\mathrm{CFWS}^{+}$are distant from each other evidence that the frequency of grade 2 injuries is not associated with treatment $\mathrm{CCCP}+\mathrm{CFWS}^{+}$. The same considerations can be made for components $\mathrm{CP}+\mathrm{CFWS}^{+}$and $\mathrm{S} 2$ (grade 2 injuries on the side) in Figure 5-C. These components are distant from each other, evidencing little association. In addition, their higher distance from the origin indicates a higher contribution to the chi-square test.

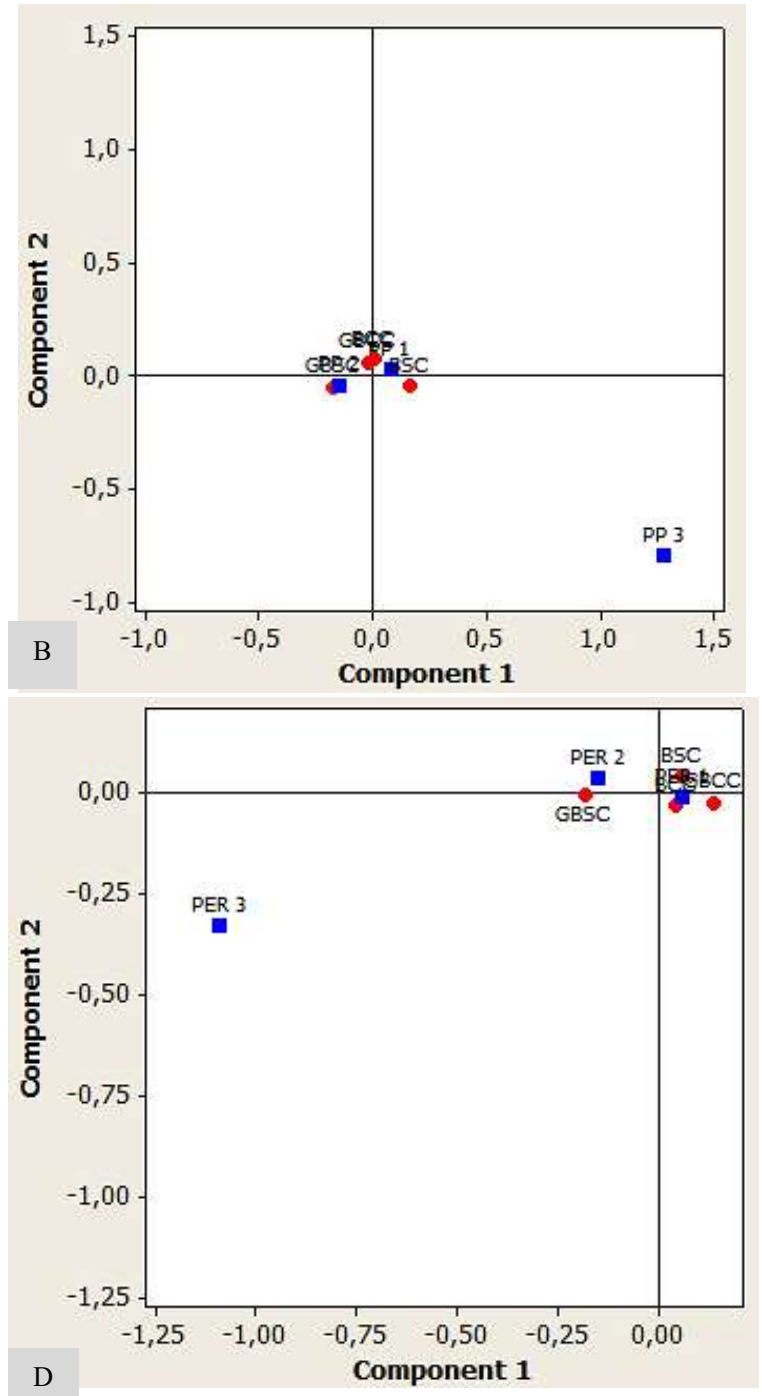

FIGURE 5. Graphical representation of the correspondence analysis of the relationship between the type of treatment and the severity of injuries in the head (A), neck/shoulder (B), belly/loin (C), and legs (D). 
Despite the evidence presented in this present study that the use of bedding decreased the incidence of body injuries, the frequency of aggressive behavior in these treatments was similar to that of previous studies. The methodology used for behavioral analysis (focal sampling) may not identify differences in this behavioral pattern between the treatments.

Arey \& Edwards (1998) performed a literature review on the aggressive behavior of sows during social mixing and found that the presence of bedding on the pens did not significantly affect the level of aggressiveness. In contrast, our results demonstrated that the presence of bedding decreased the level of body injuries from aggressive social behavior in sows, especially in the head and neck/shoulder regions. The means and standard deviations of the reproductive variables are shown in Tables 3 and 4. During the study period, some losses were disregarded from the analysis related to return to estrus, abortions, and deaths. Because the sows used in the treatments $\mathrm{CCP}+\mathrm{CFWS}^{-}$and $\mathrm{CCCP}+\mathrm{CFWS}^{+}$were not monitored from the beginning of gestation, the farrowing rates could not be compared between the treatments.

TABLE 3. Mean and standard deviation of the number of days of gestation (DG), piglets born alive (PBA), number of stillbirths (S), number of mummified piglets (M), and mean piglet weight (MPW) according to treatment.

\begin{tabular}{cccccc}
\hline Treatment & DG & PBA & S & M & MPW \\
\hline CCP+CFWS $^{-}$ & $114.68 \pm 1.56$ & $12.84 \pm 2.46$ & $0.38 \pm 0.79$ & $0.05 \pm 0.23$ & $1.46 \pm 0.21$ \\
${\text { CCCP }+ \text { CFWS }^{+}}$ & $114.45 \pm 1.61$ & $12.00 \pm 2.64$ & $0.45 \pm 0.76$ & $0.45 \pm 0.92$ & $1.51 \pm 0.31$ \\
CP+CFWS & $114.55 \pm 1.01$ & $12.86 \pm 2.38$ & $0.31 \pm 0.88$ & $0.41 \pm 0.83$ & $1.40 \pm 0.19$ \\
CP+CFWS & $114.23 \pm 1.31$ & $11.84 \pm 2.76$ & $0.29 \pm 0.78$ & $0.61 \pm 0.99$ & $1.46 \pm 0.22$ \\
\hline
\end{tabular}

TABLE 4. Number and percentage of return to estrus (RE), abortions (A) and deaths (D) in the study period according to treatment.

\begin{tabular}{|c|c|c|c|c|c|c|}
\hline \multirow{2}{*}{ Treatment } & \multicolumn{2}{|c|}{$\mathrm{RE}$} & \multicolumn{2}{|c|}{ A } & \multicolumn{2}{|c|}{$\mathrm{D}$} \\
\hline & $\mathrm{N}$ & $\%$ & $\mathrm{~N}$ & $\%$ & $\mathrm{~N}$ & $\%$ \\
\hline $\mathrm{CCP}+\mathrm{CFWS}^{-}$ & - & - & 1 & 1.9 & - & - \\
\hline $\mathrm{CCCP}+\mathrm{CFWS}^{+}$ & - & - & 1 & 1.9 & - & - \\
\hline $\mathrm{CP}+\mathrm{CFWS}^{-}$ & 5 & 9.2 & 2 & 3.7 & - & - \\
\hline $\mathrm{CP}+\mathrm{CFWS}^{+}$ & 4 & 7.4 & 1 & 1.9 & 1 & 1.9 \\
\hline
\end{tabular}

The model developed for the gestation period considered the effects of parity, type of pen, and type of treatment, and only parity was significant $(\mathrm{p}<0.05)$. The simple linear regression model estimated that the increase of one unit in parity caused an approximate increase of 0.25 days in the entire gestation period of the sows. Despite the high significance of the effect of parity on the gestation period, the coefficient of determination $\left(\mathrm{r}^{2}\right)$ was low $(11 \%)$, indicating that parity contributes to the gestation period, but other factors affect gestation more strongly than parity in isolation. Pen type, parity, and treatment had no significant effects on the number of piglets born alive. Therefore, the housing system (CP and a CCP) and the presence of wood shaving bedding did not significantly affect the number of piglets born alive.

Data on the stillbirth rate were treated as binary responses, and the logistic regression model applied to this variable detected a significant effect of parity, without a significant effect of treatment and type of pen. This analysis indicated that for each increase of one unit in parity, the chance of stillbirths was increased 1.3-fold. In contrast, the housing system and type of floor did not affect the stillbirth rate. The logistic regression analysis demonstrated that the type of treatment significantly affected the number of mummified piglets. The treatment $\mathrm{CP}+\mathrm{CFWS}^{+}$was 11 times more likely to produce mummified piglets than $\mathrm{CCP}+\mathrm{CFWS}^{-}(\mathrm{p}<0.003)$. The mean weight of piglets was analyzed using a simple linear regression model, which showed no significant effects on this parameter.

Arey \& Edwards (1998) reported some practical implications from aggressive behavior during the social mixing of pregnant sows. These behaviors generate physiological responses to stress, which may impair reproductive performance. Nonetheless, these behaviors can be avoidable if exposure to social stress occurs at a time different from that of embryo implantation. However, in the present study, of all evaluated parameters, only the number of mummified piglets was negatively affected by social mixing during embryo implantation, specifically in the treatment $\mathrm{CP}+\mathrm{CFWS}^{+}$. Cassar et al. (2008) evaluated the effect of social mixing of sows at different stages of gestation. The groups subjected to social mixed were evaluated after $2,7,14,21$, and 28 days of artificial insemination, and the effects on the number of piglets born alive and rate of calving were determined. Neither gestation stage nor social mixing had significant effects on the studied fertility parameters.

Similarly, the current findings show the lack of significant differences in the number of piglets born alive according to the type of housing (with social mixing at 5 and 28 days of gestation) and the type of floor in collective housing systems.

\section{CONCLUSIONS}

1. The presence of wood shaving bedding in collective housing systems changed the postural pattern of pregnant sows, and sows maintained on concrete floors remained less in the lying position;

2. The presence of bedding in collective housing systems modified the pattern of activities performed by pregnant sows, and the frequency of oral stereotypies was decreased; 
3. The use of bedding decreased the incidence of body injuries after one week of collective housing, indicating the lower effect of aggressive behavior during the formation of social hierarchy;

4. The type of housing did not significantly affect animal behavior;

5. The type of housing did not significantly affect the frequency and severity of injuries in sows after social mixing;

6. The presence of bedding did not significantly affect the gestation period, the number of piglets born alive, stillbirth rate, and the mean weight of piglets at birth. However, the number of mummified piglets was higher in the collective housing system with bedding.

\section{REFERENCES}

Andersen HML, Jorgensen E, Dybkjar L, Jorgensen B (2008) The ear skin temperature as an indicator of the thermal comfort of pigs. Applied Animal Behaviour Science 113:43-56.

Arey DS, Edwards SA (1998) Factors influencing aggression between sows after mixing and the consequences for welfare and production. Livestock Production Science 56:61-70.

Averós X, Brossard L, Dourmad JY, Greefc KH, Edge HL, Edwards SA, Meunier-Salaun MC (2010) A meta-analysis of the combined effect of housing and environmental enrichment characteristics on the behaviour and performance of pigs. Applied Animal Behaviour Science 127:73-85.

Bergeron R, Badnell-Waters AJ, Lambton S, Mason G (2006) Stereotypic Oral Behaviour in Captive Ungulates: Foraging, Diet and Gastrointestinal Function. Guelf, Cab International, 234p.

Brown-Brandl TM, Eigenberg RA, Nienaber JA, Kachman SD (2001) Thermoregulatory profile of a newer genetic line of pigs. Livestock Production Science 71:253-260.

Cassar G, Kirkwood RN, Seguin MJ, Widowski TM, Farzan A, Zanella AJ, Friend Ship RM (2008) Influence of stage of gestation at grouping and presence of boars on farrowing rate and litter size of group-housed sows. Journal of Swine Health and Production 16:81-85.

Corrêa EK, Bianchi I, Ulguim RR, Corrêa MN, Gil-Turnes C, Lucia Júnior T (2009) Effects of different litter depths on environmental parameters and growth performance of growing finishing pigs. Ciência Rural 39:838-843.

Coser F (2014) Bem-estar animal:suinocultura brasileira deve abolir as gaiolas de gestação. Available: http://www.porkworld.com.br/noticia/bem-estaranimalsuinocultura-brasileira-deve-abolir-as-gaiolas-degesta. Accessed: Jan 7, 2014.

English PR, Smith WJ, Maclean A (1982) The sow improving her efficiency. New York, Farming Press, 311p.

Fraser AF, Phillips PA, Thompson BK, Tennessen T (1991) Effect of straw on the behaviour of growing pigs. Applied Animal Behaviour Science 30:307-318.
Ison SH, D'eath RB, Robson SK, Baxter EM, Ormandy E, Douglas AJ, Russell JA, Lawrence AB, Jarvis S (2010) 'Subordination style' in pigs? The response of pregnant sows to mixing stress affects their offspring's behaviour and stress reactivity. Applied Animal Behaviour Science 124:16-27.

Jansen J, Kirkwood RN, Zanella AJ, Tempelman RJ (2007) Influence of gestation housing on sow behavior and fertility. Journal of Swine Health and Production 15:132-136.

Jensen MB, Studnitz M, Pedersen LJ (2010) The effect of type of rooting material and space allowance on explorative and abnormal behaviour in growing pigs. Applied Animal Behaviour Science 123:87-92.

Karlen G, Hemsworth PH, Gonyou HWG, Fabrega E, Strom AD, Smits RJ (2007) The welfare of gestating sows in conventional stalls and large groups on deep litter. Applied Animal Behaviour Science 105:87-101.

Kiefer C, Meignen BCG, Sanches JF, Carrijo AS (2009) Resposta de suínos em crescimento mantidos em diferentes temperaturas. Archivos de Zootecnia 58:55-64.

Lima AL, Oliveira RFM, Donzele JL, Fernandes HCF, Campos PHRF, Antunes MVL (2011) Resfriamento do piso da maternidade para porcas em lactação no verão. Revista Brasileira de Zootecnia 40:804-811.

MINITAB (2011) Minitab user's guide: statisticas. Ver. 16. Stage College: Minitab.

Moura DJ (1999) Ventilação na suinocultura. Piracicaba: Fundação de Estudos Agrários Luiz de Queiroz, 179p.

Munsterhjelm C, Peltoniemim OAT, Heinonen M, Halli O, Karhapaa M, Valros A (2009) Experience of moderate bedding affects behaviour of growing pigs. Applied Animal Behaviour Science 118:42-53.

Oliva A, Tama B, Elias D, Barboza K, Pereira DA, Oliveira LG (2014) Aspectos de bem-estar relacionados a matrizes suínas alojadas em celas individuais. Relato de Caso. Revista Brasileira de Higiene e Sanidade Animal 8:89-104.

Pandorfi H (2005) Comportamento bioclimático de matrizes suínas em gestação e o uso de sistemas inteligentes na caracterização do ambiente produtivo: suinocultura de precisão.199p. Tese Doutorado em Engenharia Agrícola, Piracicaba, Universidade de São Paulo, Escola Superior de Agricultura Luiz de Queiroz.

PORKWORD. JBS anuncia fim das gaiolas de gestação para porcas reprodutoras. Available:

http://www.porkworld.com.br/noticia/jbs-anuncia-fim-dasgaiolas-de-gestacao-para-porcas-reprodutoras. Accessed: Jan 7, 2015.

Remience V, Wavreille J, Canart B, Meunier-Salau“NMC, Prunier A, Bartiaux-Thill N, Nicks B, Vandenheede M (2008) Effects of space allowance on the welfare of dry sows kept in dynamic groups and fed with an electronic sow feeder. Applied Animal Behaviour Science 112:284-296.

Rodrigues VC, Silva IJO, Vieira FMC, Nascimento ST (2011) A correct enthalpy relationship as thermal comfort índex for livestock. International Journal of Biometeorology 55:455-459. 
Savary P, Gygax L, Wechsler B, Hauser R (2009) Effect of a synthetic plate in the lying area on lying behaviour, degree of fouling and skin lesions at the leg joints of finishing pigs. Applied Animal Behaviour Science 118:20-27.

Silva IJO, Pandorfi H, Piedade SMS (2008) Influência do sistema de alojamento no comportamento e bem-estar de matrizes suínas em gestação. Revista Brasileira de Zootecnia 37:1319-1329.
Sousa MS, Ferreira AS, Júnior GMO, Pires LC, Barbosa FF, Figueiredo EM (2014) Effects of farrowing system on behavior of lactating sows in winter. Revista CES Medicina Veterinaria y Zootecnia 9:84-93.

Studnitz M, Jensen MB, Pedersen LJ (2007) Why do pigs root and in what will they root? A review on the exploratory behaviour of pigs in relation to environmental enrichment. Applied Animal Behaviour Science 107:183-197. 